\title{
Oxygen transfer dynamics and activated sludge floc structure under different sludge retention times at low dissolved oxygen concentrations
}

\author{
Haitao Fan ${ }^{a}$, Xiuhong Liu a , Hao Wang a , Yunping Han ${ }^{\mathrm{b}}$, Lu Qi ${ }^{\text {a, }}{ }^{* *}$, Hongchen Wang a, * \\ ${ }^{a}$ Research Center for Low carbon technology of water environment, Renmin University of China, Beijing 100872, China \\ ${ }^{\mathrm{b}}$ Research Center for Eco-Environmental Sciences, Chinese Academy of Sciences, Beijing 100085, China
}

\section{H I G H L I G H T S}

- Oxygen diffusion feature was explored in microenvironment of floc by microelectrodes.

- Activated sludge properties in combination with nutrient removal efficiency were investigated under different SRTs at low DO conditions.

- Reactors with long SRTs were less sensitive to low DO concentrations.

- EPS increased the oxygen mass transport resistance in the floc.

- Settling performance of activated sludge improved with longer SRTs.

\section{A R T I C L E I N F O}

\section{Article history:}

Received 8 November 2015

Received in revised form

16 October 2016

Accepted 31 October 2016

Available online 27 November 2016

Handling Editor: Y Liu

\section{Keywords:}

EPS

SRT

Floc structure

Settling performance

Low DO

\begin{abstract}
A B S T R A C T
In activated sludge systems, the aeration process consumes the most energy. The energy cost can be dramatically reduced by decreasing the operating dissolved oxygen (DO) concentration. However, low DO may lead to incomplete nitrification and poor settling performance of activated sludge flocs (ASFs). This study investigates oxygen transfer dynamics and settling performances of activated sludge under different sludge retention times (SRTs) and DO conditions using microelectrodes and microscopic techniques. Our experimental results showed that with longer SRTs, treatment capacity and settling performances of activated sludge improved due to smaller floc size and less extracellular polymeric substances (EPS). Long-term low DO conditions produced larger flocs and more EPS per unit sludge, which produced a more extensive anoxic area and led to low oxygen diffusion performance in flocs. Long SRTs mitigated the adverse effects of low DO. According to the microelectrode analysis and fractal dimension determination, smaller floc size and less EPS in the long SRT system led to high oxygen diffusion property and more compact floc structure that caused a drop in the sludge volume index (SVI). In summary, our results suggested that long SRTs of activated sludge can improve the operating performance under low DO conditions.
\end{abstract}

() 2016 Elsevier Ltd. All rights reserved.

\section{Introduction}

Energy conservation is an essential issue in wastewater treatment plants (WWTPs). In the typical activated sludge process of WWTP, aeration usually accounts for approximately $50 \%$ of the total energy consumption (McCarty et al., 2011). Therefore, decreasing the operating dissolved oxygen (DO) concentration can reduce

\footnotetext{
* Corresponding author.

** Corresponding author.

E-mail addresses: qilu@ruc.edu.cn (L. Qi), whc@ruc.edu.cn (H. Wang).
}

energy consumption. Activated sludge processes are the most widely used biological solutions in WWTPs worldwide. In recent years, a number of innovative nitrogen removal processes have been developed to reduce operational costs, such as shortcut nitrification-denitrification, simultaneous nitrification/denitrification (SND), and anaerobic ammonium oxidation (anammox) (Zeng et al., 2014). Shortcut nitrification-denitrification follows the ammonia-nitrite-nitrogen gas path for the removal of ammonia. SND implies that nitrification/denitrification or nitritation/denitritation occur concurrently in one reactor under aerobic conditions. Anammox is an anaerobic-autotrophic biochemical reaction 
that can convert ammonium to nitrogen gas using nitrite as the terminal electron acceptor (Strous et al., 2006). In comparison with traditional nitrification/denitrification, these processes are under low DO conditions, which require less oxygen demand and lower energy costs.

However, there are some adverse effects of reduced DO concentrations. One problem caused by low operating DO concentrations is poor nitrification. It has already been proved that low DO concentrations inhibit the growth rate of nitrifiers and lead to incomplete nitrification (Park and Noguera, 2004). To reach effluent quality standards, actual operating DO concentrations in most WWTPs should be maintained at high levels. However, researchers have found that high DO concentrations do not strengthen the nitrification (Satoh et al., 2004). Therefore, there is no need to waste energy to maintain high level of DO in the aeration tank. Moreover, good nutrient removal efficiency can be obtained through traditional nitrification processes, even at low DO concentrations. Park and Noguera (2004) demonstrated that an activated sludge system could achieve good nitrification even with DO concentrations as low as $0.12 \mathrm{mg} / \mathrm{L}$ because the type of ammonia oxidizing bacteria (AOB) was able to adapt to low DO operating states. Liu and Wang (2013) also found that long-term low DO conditions resulted in lowering endogenous decay rate of nitrifiers, increasing sludge nitrification capacity and reducing the adverse effects of low DO on overall nitrification performance. These studies indicate that operation of the traditional nitrification process under low DO is feasible.

Another problem of operating under low DO conditions is the poor settling performance of activated sludge flocs (ASFs) in the secondary clarifier. Poor settling performance causes serious operational problems, such as ineffective return of sludge, excessive activated biosolid loss in the aerobic tank, and poor standard of suspended solid (SS) of the effluent. The settling ability of ASF is determined by various floc characteristics such as structure, growth of filamentous bacteria, and chemical composition (Wilén et al., 2008). Extracellular polymeric substances (EPS) produced by sludge microorganisms play an important role in sludge flocculation. Different floc constituents are bound together by EPS because of the electrostatic forces described by the Derjguin Landau Verwey Overbeek (DLVO) theory (Zita and Hermansson, 1994). However, it has already been proved that excessive EPS produce high negative charge densities causing the disintegration of flocs (Liao et al., 2001). Therefore, EPS have different effects on sludge flocculation. The change in EPS properties is mainly due to the changes in operating conditions, microbial community structures, and chemical make-up. Considerable research studies have only focused on individual factors influencing floc characteristics such as organic loading, DO concentrations, and sludge retention time (SRT) (Wilén and Balmér, 1999).

On the basis of the literature, it is evident that EPS and floc structures are two key parameters for energy conservation in both innovative and traditional nitrification processes. In addition, sludge filamentous bulking control is crucial under low DO operating states. ASF characteristics affect the settling performance, treatment properties, and effluent quality, and are closely related to the internal microscopic mass transfer properties such as oxygen within sludge flocs. Results obtained using microelectrode techniques have shown that DO concentration distributions were distinct in flocs of different particle sizes (Han et al., 2012). Concentrations of $\mathrm{pH}, \mathrm{NH}_{4}^{+}$, and $\mathrm{NO}_{3}^{-}$were also found to decrease from the surface to the center of activated sludge aggregates with particle sizes $\geq 1000 \mu \mathrm{m}$ (Wang et al., 2011). However, integrative studies under low DO conditions, combining EPS compositions, floc structures, mass transfer properties, and settling performances, are very limited. Therefore, we believe that microenvironmental conditions of different floc characteristics affect oxygen mass transfer efficiency and bacterial diversity.

In this study, microelectrodes were applied to analyze oxygen transfer properties in the ASF microenvironment. The relationship between floc properties and settling performance at different SRTs was explored using a two-dimensional (2D) fractal dimension. Experimental results provided important insights for developing a control strategy to improve the operating performance of WWTPs under low DO conditions.

\section{Material and methods}

\subsection{Reactors and operating conditions}

Four sets of activated sludge system were operated in parallel at $20{ }^{\circ} \mathrm{C}$. Each system comprised a glass column with a working volume of $3.5 \mathrm{~L}(\mathrm{H}=0.3 \mathrm{~m}, \varnothing=0.15 \mathrm{~m}$, effective water depth $=0.15 \mathrm{~m})$. Each column was coupled with a secondary settler with a working volume of $4.5 \mathrm{~L}(\mathrm{H}=0.55 \mathrm{~m}, \mathrm{~W}=0.09 \mathrm{~m})$ (Fig. 1).

Reactors were operated as continuous stirred-tank process (CSTP). Influent flow and return sludge were pumped by peristaltic pumps. Ceramic discs with $0.04 \mathrm{~m}$ diameter were used as fine bubble diffusers. Mixing was performed by propeller stirrers (propeller diameter $=5 \mathrm{~cm}$; speed of stirring $=150 \mathrm{rpm}$ ). The $\mathrm{O}_{2}$ concentration was determined using an LDO fluorescent DO electrode (Tengue Instrument Co., Ltd., Beijing) and adjusted to a target value by an air meter.

Hydraulic retention time (HRT) of one complete process was $6 \mathrm{~h}$. Return sludge was pumped continuously from the settler to the aeration tank, with a ratio of $100 \%$ of the influent flow. Reactors were set up at four SRTs: 10, 17.5, 25, and $35 \mathrm{~d}$. To achieve a target SRT, excess sludge was withdrawn directly from the aeration tanks daily. Each setup was run for at least three SRTs to establish steady state conditions.

Four sets of lab-scale reactors were operated at different DO conditions with different SRTs; each DO concentration was operated with at least one SRT period. DO concentration was monitored daily by using the DO electrode. To obtain a good biological nitrification effect, low DO condition of $0.5 \mathrm{mg} / \mathrm{L}$ was maintained at least three times of SRT.

\subsection{Wastewater and seed sludge}

The lab-scale reactors were fed with synthetic wastewater mainly consisting of glucose (Sinopharm Chemical Reagent Co., Ltd, 10010518, Analytical Pure), $\mathrm{NH}_{4} \mathrm{Cl}$ (10001518, Analytical Pure), and $\mathrm{KH}_{2} \mathrm{PO}_{4}$ (10017608, Analytical Pure) as the carbon source, nitrogen source, and phosphorus source, respectively. The chemical oxygen demand (COD), $\mathrm{NH}_{4}^{+}-\mathrm{N}$, and $\mathrm{PO}_{4}^{3-}-\mathrm{P}$ were controlled at $180-250$, $30-40$, and $6-8 \mathrm{mg} / \mathrm{L}$, respectively. To control the $\mathrm{COD}, \mathrm{NH}_{4}^{+}-\mathrm{N}$ and $\mathrm{PO}_{4}^{3-}-\mathrm{P}$ in the stable range, glucose, $\mathrm{NH}_{4} \mathrm{Cl}$ and $\mathrm{KH}_{2} \mathrm{PO}_{4}$ dissolved and mixed in a water bucket were added daily at a constant dose, and two duplicate samples of about $50 \mathrm{~mL}$ were taken for monitoring of $\mathrm{COD}, \mathrm{NH}_{4}^{+}-\mathrm{N}$, and $\mathrm{PO}_{4}^{3-}-\mathrm{P}$ every two days. The nutrient solution contained $\mathrm{MgSO}_{4} \cdot 7 \mathrm{H}_{2} \mathrm{O} \quad(5.6 \mathrm{mg} / \mathrm{L}), \quad \mathrm{ZnCl}_{2} \cdot 2 \mathrm{H}_{2} \mathrm{O}$ $(0.0018 \mathrm{mg} / \mathrm{L}), \mathrm{FeCl}_{3} \cdot 6 \mathrm{H}_{2} \mathrm{O}(0.88 \mathrm{mg} / \mathrm{L}), \mathrm{CaCl}_{2} \cdot \mathrm{H}_{2} \mathrm{O}(1.3 \mathrm{mg} / \mathrm{L})$, and $\mathrm{MnCl}_{2} \cdot 4 \mathrm{H}_{2} \mathrm{O}(0.19 \mathrm{mg} / \mathrm{L})$.

Seed sludge was taken from the aeration tank of Qin He WWTP in Beijing that uses a typical anaerobic-anoxic-aerobic $\left(\mathrm{A}^{2} \mathrm{O}\right)$ process to treat municipal wastewater, with good performance of complete nitrification, and $\mathrm{COD}$ and $\mathrm{NH}_{4}^{+}-\mathrm{N}$ removal rates are above $95 \%$. 

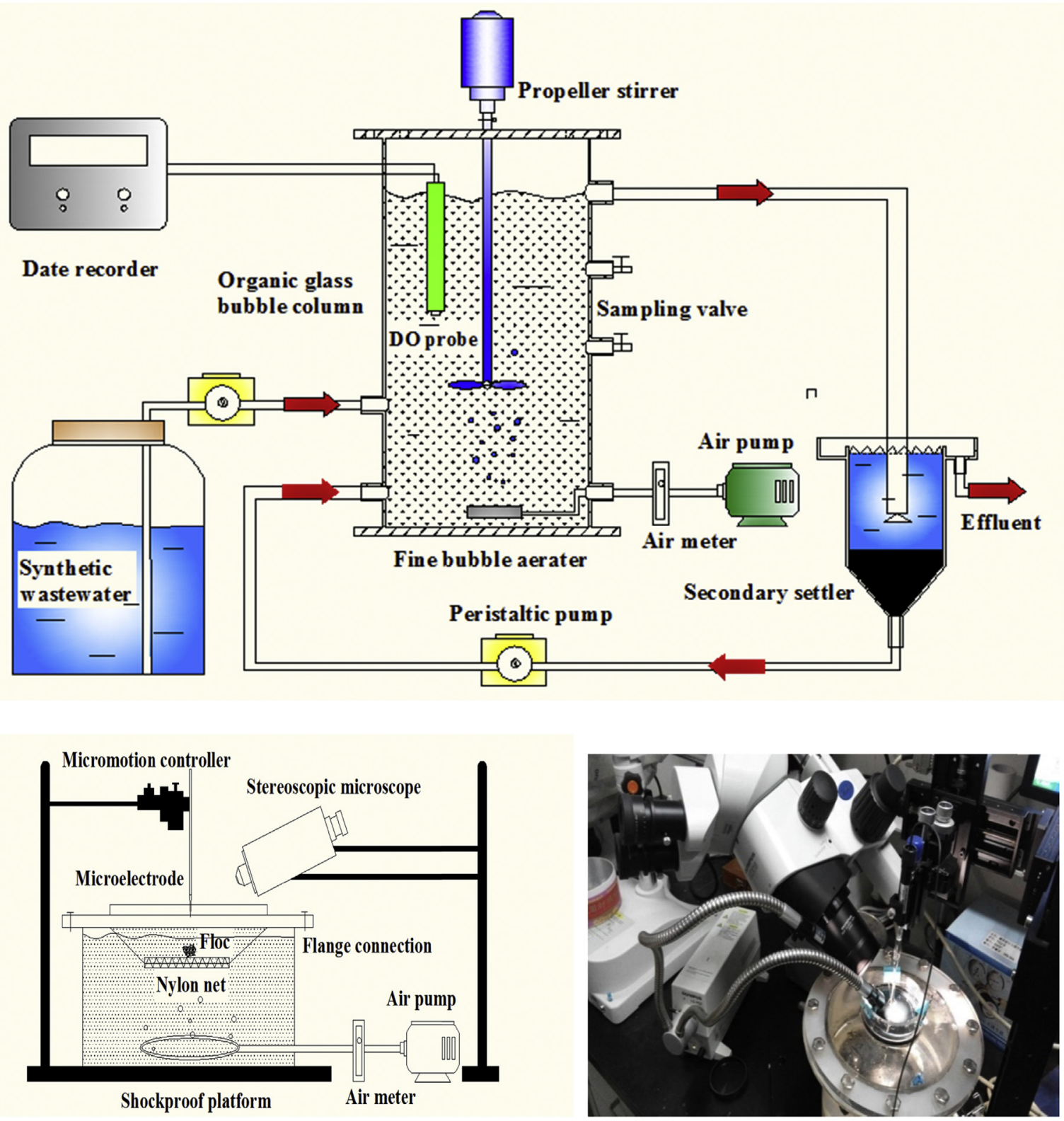

Fig. 1. Schematic diagram of lab-scale CSTP and microelectrodes test bench.

\subsection{Analytical methods}

\subsubsection{EPS extraction and chemical analysis}

Method for extracting EPS was modified according to the heating procedure (Yu et al., 2013). First, 15-mL raw sludge sample was taken from the reactors and centrifuged at $6000 \mathrm{rpm}$ for $10 \mathrm{~min}$. The supernatant was filtered through a glass fiber syringe filter with $1.0 \mu \mathrm{m}$ pore size to intercept the residual sludge flocs, and the supernatant was collected for further analysis. The bottom sediments were resuspended to their original volume with phosphate buffer solution consisting of $0.790 \% \mathrm{NaCl}, 0.020 \% \mathrm{KCl}, 0.142 \%$ $\mathrm{Na}_{2} \mathrm{HPO}_{4}$, and $0.024 \% \mathrm{KH}_{2} \mathrm{PO}_{4}$. This mixed liquor was treated in $60{ }^{\circ} \mathrm{C}$ water bath heating for $1 \mathrm{~h}$, and centrifuged again at $6000 \mathrm{rpm}$ for $10 \mathrm{~min}$. The organic matter present in the supernatant, soluble EPS solution was filtered using polytetrafluoroethylene membranes with a pore size of $0.45 \mu \mathrm{m}$ before chemical composition analysis.

Protein concentration was determined with the Lowry method
(Lowry et al., 1951), using bovine serum albumin as a reference (BSA, Sigma, Poole, UK). Polysaccharides concentration was measured according to the colorimetry of sulfuric acid-anthrone method using glucose as the standard (Dubois et al., 1956). DNA was analyzed by diphenylamine chromogenic method using calfthymus DNA as the standard (Sigma, Poole, UK).

COD was analyzed using rapid COD tester (WTW, PhotoLabS6, Germany). Ammonia ( $\left.\mathrm{NH}_{4}^{+}-\mathrm{N}\right)$, mixed liquor suspended solid (MLSS), and sludge volume index (SVI) were determined according to APHA standard methods (APHA, AWWA, WEF, 1999). The samples for $\mathrm{NH}_{4}^{+}-\mathrm{N}$ were filtered with $0.45-\mathrm{mm}$ membrane filters before analysis.

\subsubsection{Determination of ASF size distribution and structure}

ASF size was measured on-site by a laser particle analyzer Malvern Mastersizer 2000, (Malvern Instruments, Ltd, Malvern, $\mathrm{UK})$, with a measurement range of $0.02-2000 \mu \mathrm{m}$, which works on 
the principle of laser detraction. Before measurement, the sludge samples were diluted with synthetic wastewater for 10 duplicates for the precise measurement of particle size distribution (PSD) using the particle analyzer. Three measurements were conducted on each sample. Because of the larger range of size of the flocs, the mean particle size $d_{50}$ and $d[4,3]$ were calculated. $d_{50}$ means the particle size of undersize cumulative percentage achieve $50 \%$ of the total particles. This helps in understanding the changes caused by different SRTs under low DO conditions (Wu et al., 2009). d[4,3] is used to represent the volume diameter:

$\mathrm{d}[4,3]=\sum f_{i} d_{i}$

where,

$\mathrm{f}_{\mathrm{i}-}$ percentage of total volume of i size interval;

$\mathrm{d}_{\mathrm{i}}$ - average size of i size interval.

Since the Malvern laser diffraction method initially calculates volume distribution, it is convenient to use $\mathrm{d}[4,3]$ to calculate the average particle size.

Fractal dimension is the most representative parameter to describe floc structure because of its capability to describe selfsimilar and complex structures of real flocs. Thus, in this study, 2D fractal dimension was measured with the Chakraborti et al. (2000) image method:

$\mathrm{D}=\frac{\ln (A)}{\ln (P)}$

where,

D - two-dimensional dimension of flocs, $1<\mathrm{D}<2$;

A - area of flocs;

$P$ - perimeter of the flocs.

Because of irregular shapes of the ASF, it is necessary to process the floc images to calculate their geometric surface area. Flocs were photographed using optical microscope (BX51, Olympus Ltd, Japan) combined with a charge coupled device camera. The floc images were colored and analyzed by Image-Pro Plus 6.0 (Media Cybernetics, Inc, US) to calculate A and P. The 2D dimensions of flocs in all the reactors under different SRTs were detected five times, and average results were adopted.

\subsubsection{Microelectrode analysis}

Glass chamber with a nylon net was used to keep the floc particles suspended and stationary in the mixed liquid, as presented by $\mathrm{Li}$ and Bishop (2004). $\mathrm{Na}_{2} \mathrm{SO}_{3}$ can consume oxygen to generate $\mathrm{Na}_{2} \mathrm{SO}_{4}$. Thus, $\mathrm{DO}$ concentration in the chamber can be adjusted by adding $\mathrm{Na}_{2} \mathrm{SO}_{3}$ during measurement. DO concentration was adjusted to keep the flocs at the same DO concentrations in the labscale reactors.

Microelectrodes with $10-\mu \mathrm{m}$ tip diameter (Unisense Piocammeter PA2000, Denmark) were used to measure DO in flocs of different SRTs and sizes. The step of detection was $20 \mu \mathrm{m}$, which was operated automatically by a micromanipulator. The sludge samples were left in the chamber for $10 \mathrm{~min}$ before measurements started. Each floc was measured for three times.

All the results for PSD and the floc morphology were taken at $0.5 \mathrm{mg} / \mathrm{L}$ DO condition.

\section{Results and discussion}

\section{1. $\mathrm{COD}$ and $\mathrm{NH}_{4}^{+}-\mathrm{N}$ removal with different SRTs}

Fig. 2 shows the COD removal and nitrification performance of $10,17.5,25$, and $35 \mathrm{~d}$ SRTs reactors. The COD concentration of the influent was in the range of $180-250 \mathrm{mg} / \mathrm{L}$. When operated at different DO levels, effluent COD concentrations in the 10 and $17.5 \mathrm{~d}$ SRTs reactors were $\leq 50 \mathrm{mg} / \mathrm{L}$ (equivalent to class $\mathrm{A}$, urban sewage treatment plant nutrient discharge standard of China, GB, 189182002), and COD removal efficiency was $\geq 80 \%$ (Fig. 2 [1]); effluent COD concentrations in 25 and $35 \mathrm{~d}$ SRT reactors were all $\leq 20 \mathrm{mg} / \mathrm{L}$, and COD removal efficiency was $\geq 90 \%$. Even under extremely low DO conditions $(<0.3 \mathrm{mg} / \mathrm{L})$, COD was removed effectively with high SRTs. It was evident that as long as enough oxygen was supplied by aeration, the ability of reactors to remove COD was not substantially limited by low DO concentrations in the liquid.

Nitrifying bacteria are more sensitive to environmental factors and less competitive in utilizing DO than heterotrophic bacteria (Guo et al., 2009; Chang et al., 2011). In contrast to COD, the removal efficiency of $\mathrm{NH}_{4}^{+}-\mathrm{N}$ was therefore evidently influenced by DO concentrations. As shown in Fig. 2[2], when the influent $\mathrm{NH}_{4}^{+}-\mathrm{N}$ in the $10 \mathrm{~d}$ SRT reactor was in the range of $30-40 \mathrm{mg} / \mathrm{L}$, DO concentrations were $>1.2 \mathrm{mg} / \mathrm{L}$, and an $\mathrm{NH}_{4}^{+}-\mathrm{N}$ removal rate of $80 \%$ could be achieved. When DO concentrations were above $1.5 \mathrm{mg} / \mathrm{L}$, the average value of effluent $\mathrm{NH}_{4}^{+}-\mathrm{N}$ concentrations was about $4.67 \mathrm{mg} / \mathrm{L}$, which is equivalent to class $\mathrm{A}$ ( $=5 \mathrm{mg} / \mathrm{L}$, urban sewage treatment plant nutrient discharge standard of China, GB, 189182002). In the $17.5 \mathrm{~d}$ SRT reactor, the achieved $\mathrm{NH}_{4}^{+}-\mathrm{N}$ removal rate was $80 \%$ with DO concentrations $>0.8 \mathrm{mg} / \mathrm{L}$. With DO concentrations $>1.0 \mathrm{mg} / \mathrm{L}$, the average value of effluent $\mathrm{NH}_{4}^{+}-\mathrm{N}$ concentrations of $4.35 \mathrm{mg} / \mathrm{L}$ was achieved. Similar results were obtained in other reactors with different SRTs. With the further decrease in DO concentrations, the effluent $\mathrm{NH}_{4}^{+}-\mathrm{N}$ increased.

From Fig. 2, it can be noted that nitrification efficiency improved with increasing SRTs under low DO conditions. In the $10 \mathrm{~d}$ SRT reactor, with decrease in DO to $1.0 \mathrm{mg} / \mathrm{L}$, the average value of effluent $\mathrm{NH}_{4}^{+}-\mathrm{N}$ concentration increased to $10 \mathrm{mg} / \mathrm{L}$. However, in the $17.5 \mathrm{~d}$ SRT reactor, with DO concentrations of $1.0 \mathrm{mg} / \mathrm{L}$, the average value of effluent $\mathrm{NH}_{4}^{+}-\mathrm{N}$ concentrations was within class $\mathrm{A}$ standard. No changes were made to $\mathrm{NH}_{4}^{+}-\mathrm{N}$ loading, temperature, or $\mathrm{pH}$. With a further increase in SRT to $25 \mathrm{~d}$, the average value of effluent $\mathrm{NH}_{4}^{+}-\mathrm{N}$ concentrations of $4.46 \mathrm{mg} / \mathrm{L}$ was achieved, even with a decrease in DO to approximately $0.5 \mathrm{mg} / \mathrm{L}$. In the $35 \mathrm{~d}$ SRT reactor, a lower DO of $0.3 \mathrm{mg} / \mathrm{L}$ also allowed good nitrification performance. Tables $1 \mathrm{a}$ and $1 \mathrm{~b}$ shows that effluent $\mathrm{COD}$ and $\mathrm{NH}_{4}^{+}-\mathrm{N}$ from longer SRTs reactors could qualify for China's class A standard, even with low DO concentrations.

In terms of nutrient removal, long SRTs are less sensitive to low DO concentrations. Earlier studies indicated that biomass concentrations of $\mathrm{AOB}$ and NOB could be increased to reduce the adverse effects of low DO (Liu and Wang, 2013). In addition, early researchers found that under long-term low DO condition, nitrifiers' endogenous decay rate was reduced, whereas nitrifiers with oxygen affinity was enhanced. Therefore, the microbial properties of growth kinetics and oxygen adsorption kinetics are very important to nitration. In fact, activated sludge characteristics are as important as microbial properties. The experiments described below found that in different SRTs reactors, low DO concentrations produced different chemical compositions and structures of ASF, resulting in differences in nutrient removal efficiencies and settling performance.

\subsection{EPS composition change and influence on oxygen diffusion dynamics}

To analyze ASF constituents, reactors with different SRTs were run under low DO conditions (approximately $0.5 \mathrm{mg} / \mathrm{L}$ ) for at least three times at each SRT. EPS is one of most important characteristics of ASF. As shown in Table 2, the major constituent of EPS was protein, which accounted for more than half of the total EPS concentration. Moreover, the EPS concentration per unit.MLSS 

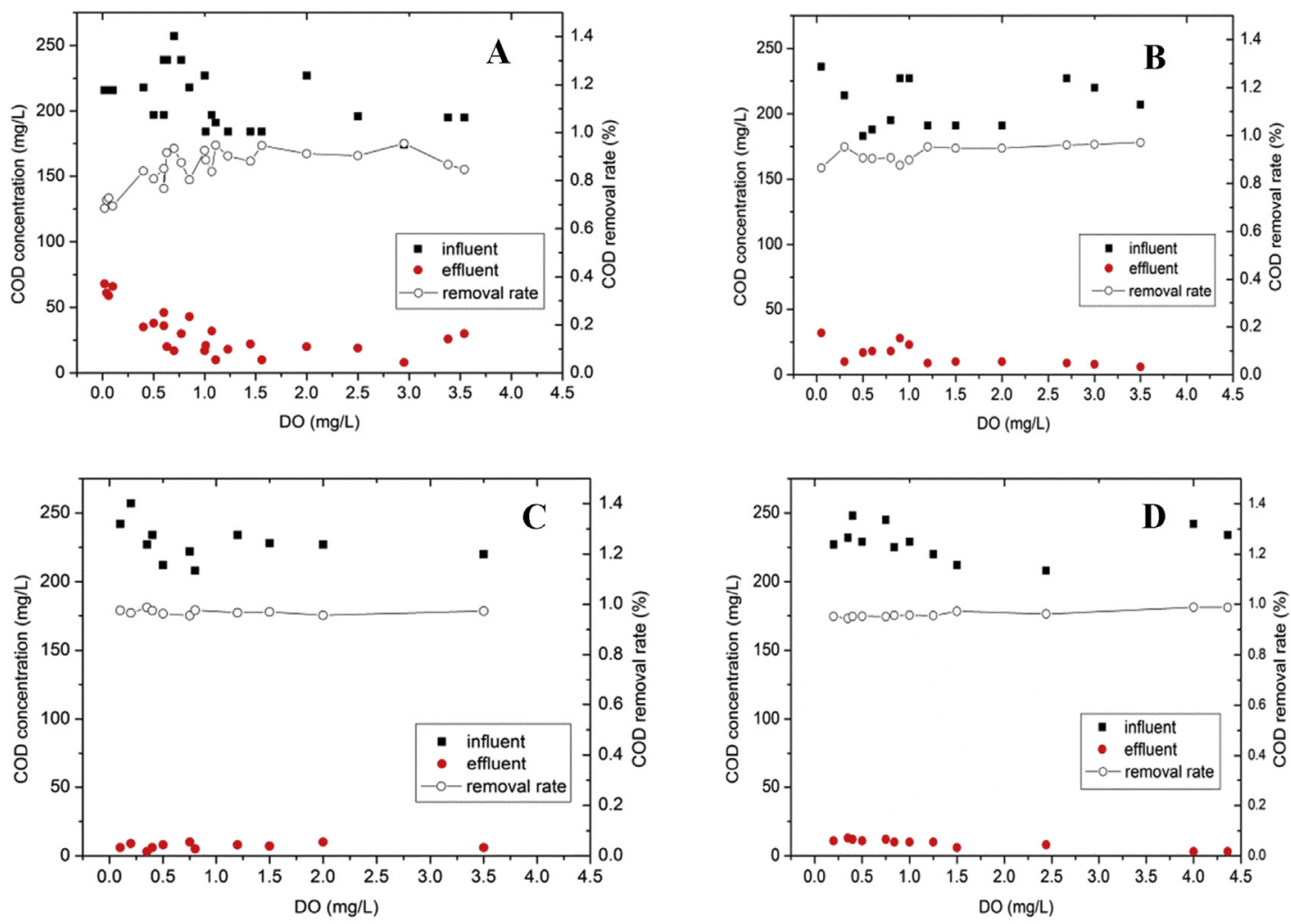

[1]
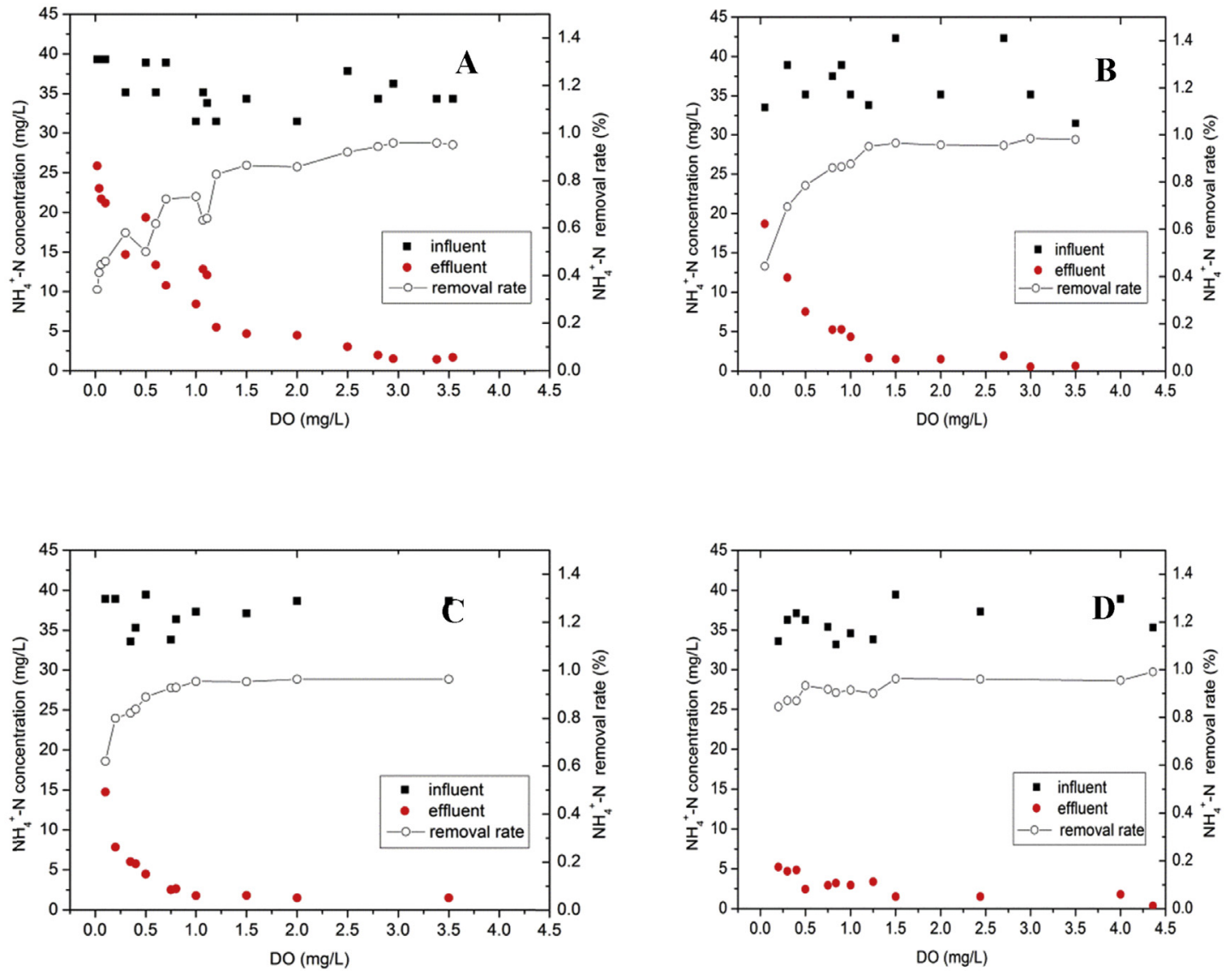

[2]

Fig. 2. Influent and effluent quality under different DO concentrations in different SRT systems ([1] COD [2] NH$H_{4}^{+}-\mathrm{N}, \mathrm{A}: \mathrm{SRT}=10 \mathrm{~d}, \mathrm{~B}: \mathrm{SRT}=17.5 \mathrm{~d}$, C: SRT $=25 \mathrm{~d}$, D: SRT $=35 \mathrm{~d}$ ) 
Table 1a

DO concentrations for effluent COD achieve class A in different SRTs reactors.

\begin{tabular}{|c|c|c|c|c|}
\hline SRT (d) & DO concentration to achieve class $\mathrm{A}(\mathrm{mg} / \mathrm{L})$ & Average influent $(\mathrm{mg} / \mathrm{L})$ & Average effluent (mg/L) & Removal rate (\%) \\
\hline 10 & 1.50 & 208.03 & 30.24 & 85.56 \\
\hline 17.5 & 0.80 & 207.46 & 15.23 & 92.73 \\
\hline 25 & 0.50 & 223.40 & 7.10 & 96.79 \\
\hline 35 & 0.30 & 223.83 & 6.83 & 96.90 \\
\hline
\end{tabular}

Table 1b

DO concentrations for effluent $\mathrm{NH}_{4}^{+}-\mathrm{N}$ achieve class A in different SRTs reactors.

\begin{tabular}{|c|c|c|c|c|}
\hline SRT (d) & DO concentration to achieve class A (mg/L) & Average influent (mg/L) & Average effluent (mg/L) & Removal rate (\%) \\
\hline 10 & 1.50 & 34.36 & 4.67 & 80.88 \\
\hline 17.5 & 0.80 & 35.16 & 5.04 & 86.02 \\
\hline 25 & 0.50 & 39.44 & 4.46 & 82.09 \\
\hline 35 & 0.30 & 36.28 & 4.70 & 87.05 \\
\hline
\end{tabular}

Table 2

Chemical composition analysis of EPS with different SRTs.

\begin{tabular}{|c|c|c|c|c|c|c|}
\hline SRT & $\operatorname{MLSS}(\mathrm{mg} / \mathrm{L})$ & Total EPS (mg/L) & EPS per unit (mg/g $\cdot$ MLSS) & Protein per unit (mg/g $\cdot$ MLSS) & Polysaccharide per unit (mg/g $\cdot$ MLSS) & DNA per unit (mg/g $\cdot$ MLSS) \\
\hline 10 & 1733 & 500.84 & 289 & 334.67 & 11.17 & 155 \\
\hline 17.5 & 2565 & 475.33 & 274 & 358.45 & 3.54 & 113 \\
\hline 25 & 3521 & 429.56 & 122 & 330.26 & 6.80 & 92.5 \\
\hline 35 & 5546 & 560.15 & 101 & 434.89 & 16.08 & 109.17 \\
\hline
\end{tabular}

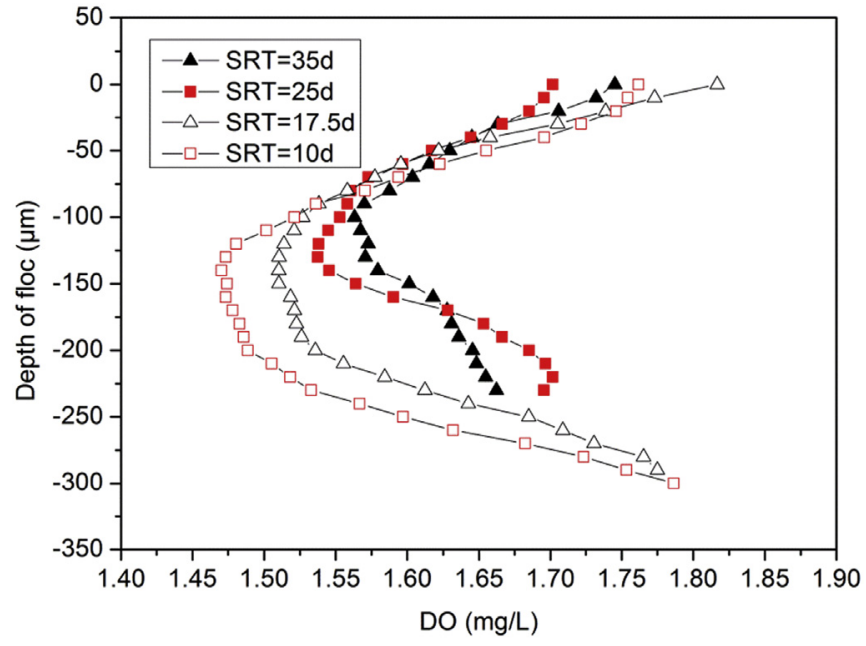

Fig. 3. Distribution of DO concentrations in ASFs with different SRTs.

increased with increasing SRTs, and when SRT was shorter than $25 \mathrm{~d}$, the protein percentage increased with increasing SRTs, which was similar to the findings of Liao et al. (2001). In this study, the protein percentages were $66.8,75.4,76.9$, and 77.6 in $10,17.5,25$, and $35 \mathrm{~d}$ SRT reactors, respectively. There were no large differences in DNA concentrations among the different SRTs. This was probably because the substrate was relatively abundant, and cell autolysis was not obvious. There were small amounts of polysaccharide in the EPS. Because the glucose in the synthetic wastewater was easily biodegraded, there was no excessive accumulation in the flocs. From the data shown in Table 2, it can be observed that there was no significant relationship between total EPS concentration and SRT. However, biomass concentrations increased from $1733 \mathrm{mg} / \mathrm{L}$ in the $10 \mathrm{~d}$ SRT reactor to $5546 \mathrm{mg} / \mathrm{L}$ in the $35 \mathrm{~d}$ SRT reactor. The EPS quantity per sludge unit halved with increase in SRTs, decreasing from $0.289 \mathrm{mg} /(\mathrm{mg} \cdot \mathrm{MLSS})$ to $0.101 \mathrm{mg} /(\mathrm{mg} \cdot \mathrm{MLSS})$.

EPS act as a floc matrix promoting flocculation; they are bound

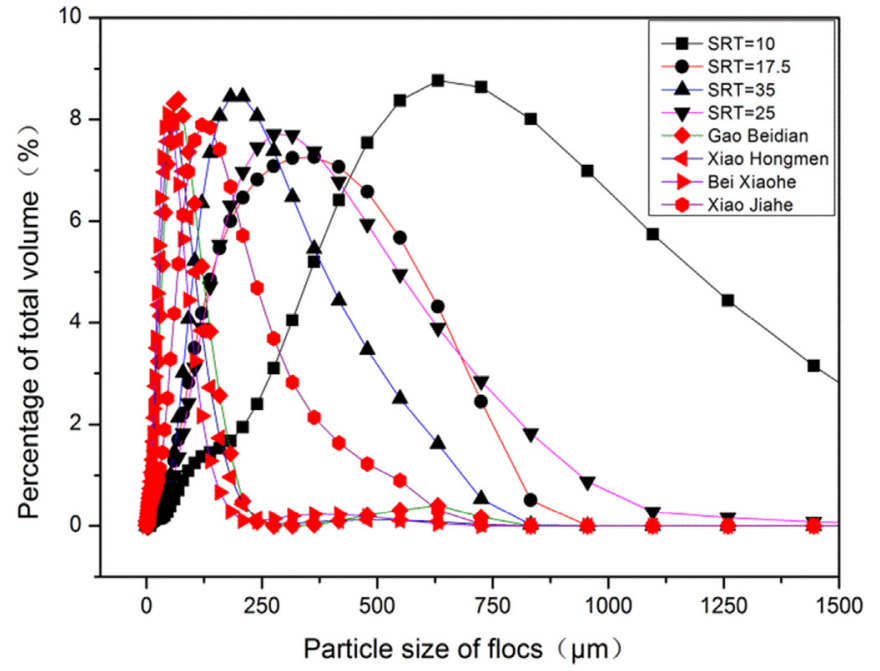

Fig. 4. Particle size distribution of ASF from lab-scale reactors.

to the cells and thus form part of the solid phase, mainly of microbial origin (Wingender et al., 1999). Therefore, they also have an effect on oxygen mass transfer from liquid into cells. Oxygen mass transfer efficiency is one of the key reasons for distinct treatment performances at different SRTs. DO distribution properties of ASF at different SRTs were detected using microelectrode techniques, as shown in Fig. 3. To evaluate the oxygen transfer performance under a common DO condition of WWTPs, DO concentration in the test reactor was set in the range of $1.5-2 \mathrm{mg} / \mathrm{L}$, and the floc diameter in the samples was in the range of $250-300 \mu \mathrm{m}$. The interface of liquid and floc was set to a depth of $0 \mu \mathrm{m}$. The oxygen diffusion rate was calculated on the basis of DO concentrations at every $10 \mu \mathrm{m}$ depth of flocs.

As illustrated in Fig. 3, the DO profiles showed a slight difference between 0 and $50 \mu \mathrm{m}$ depth at different SRTs. However, the DO profiles in the inner layer between 100 and $200 \mu \mathrm{m}$ depth showed a 
decreasing tendency of the flocs from SRT $=10 \mathrm{~d}$ to SRT $=35 \mathrm{~d}$. In the flocs of SRT $=10 \mathrm{~d}$, the DO concentration decreased from $1.76 \mathrm{mg} / \mathrm{L}$ (at the floc surface) to $1.47 \mathrm{mg} / \mathrm{L}$ (at the depth of $140 \mu \mathrm{m}$ ), with a depletion of $0.3 \mathrm{mg} / \mathrm{L}$. In the flocs of SRT $=35 \mathrm{~d}$, the DO concentration decreased from $1.75 \mathrm{mg} / \mathrm{L}$ (at the floc surface) to $1.57 \mathrm{mg} / \mathrm{L}$ (at the depth of $150 \mu \mathrm{m}$ ), with a depletion of $0.18 \mathrm{mg} / \mathrm{L}$. The depletion of DO concentrations from floc surface to core was enhanced with increasing SRT. Although DO penetration thickness was changeable with the floc sizes, an anoxic zone was not present in ASF when the bulk oxygen concentration was steady at $1.5-2 \mathrm{mg} / \mathrm{L}$. It implied that the operating DO concentration could be controlled lower for insuring the DO abundant in the floc core, and had a slight effect on nitrification.

By comparing the DO profile at different SRTs, we can deduce that a high influent $\mathrm{F} / \mathrm{M}$ ratio resulted in a sharper depletion in the oxygen concentration (influent nutrient concentrations remained the same but MLSS increased from 1733 to $5546 \mathrm{mg} / \mathrm{L}$ when SRTs increased from 10 to $35 \mathrm{~d}$ ). High organic concentration was directly correlated with the oxygen utilization in the floc, causing high biomass growth and EPS secretion, which increased the mass transport resistance in the floc (Zhou et al., 2008).

Because of the effect of the floc structure, the oxygen diffusion rate in the flocs also gradually increased with increasing SRTs. With an increase in SRTs from 10 to $35 \mathrm{~d}$, the oxygen diffusion increased from 0.0023 to $0.0032 \mathrm{mg} / \mu \mathrm{m} \cdot \mathrm{L}$. Microelectrode analysis results show that DO distribution in the inner zone along the flocs radius had a relatively large effect on the oxygen mass diffusion rate. Some researchers inferred that soluble microbial products (SMP) obstruct the passage of oxygen from air bubbles to the floc surface because of surfactants in the SMP. (Mueller et al., 2002; Fan et al., 2014). Surfactants in the wastewater liquid phase are found to have a major effect on the oxygen transfer rate (WEF and ASCE, 2001; Mueller et al., 2002). The composition of EPS is similar to that of SMP. Further, EPS may become SMP as EPS shed and possibly as the pH changes (Namkung and Rittmann, 1986). The effect of EPS on the oxygen transfer parameters could therefore be explained by the presence of surfactants in microbial secretions.

Transformation of EPS constituents may influence the nutrient removal efficiency. To reach active sites, the oxygen contained in the liquid needs to penetrate the EPS surrounding the flocs, and then diffuse through the bacterial cell membrane. We speculate that higher EPS quantity per sludge unit detected in shorter SRT reactors may have caused oxygen diffusion resistance between liquid and microorganisms. This suggests that EPS may be one of the factors that influence oxygen transfer efficiency and nitrification performance of ASF.

\subsection{Floc structure and settling performance transformation}

EPS also influence the physical properties of flocs. This section describes the transformation of floc structure and settling performance in different SRTs.

\subsubsection{Size distribution of ASF under low DO conditions}

In WWTPs, PSD is an important parameter for evaluating physical, chemical, and biological treatment processes (Barbusinski and Koscielniak, 1995; Dulekgurgen et al., 2006; Karaham et al., 2008). As shown in Fig. 4, the largest particle size percentage of total volume were $631.0,363.1,275.4$, and $182.0 \mu \mathrm{m}$ at different SRTs of $10,17.5,25$, and $35 \mathrm{~d}$, respectively, under low DO conditions. In general, the floc size was mainly about $200 \mu \mathrm{m}$. Thus, ASFs were generally large under low DO conditions in most reactors. The size distribution of flocs was in the range from 4.4 to $2187.8 \mu \mathrm{m}$. We had taken activated sludge samples from WWTPs in Beijing (Gaobeidian, Xiao Hongmen, Bei Xiaohe, Xiao Jiahe), and the largest particle size percentage of flocs was in the range of 70-200 $\mu \mathrm{m}$. Flocs tended to be larger in lab-scale systems than in full-scale plants because synthetic wastewater is rich in easily degradable organic matter and poor in SSs. When the reactor was operated at $10 \mathrm{~d}$ SRT, the largest floc diameter measured with the Malvern instrument was $631.0 \mu \mathrm{m}$, accounting for $8.77 \%$ of the total volume $\left(\mathrm{d}_{50}=549.5 \mu \mathrm{m}\right)$. When SRT was increased to $17.5 \mathrm{~d}$, the particle size of flocs remained large, with the prevalent floc diameter being $363.1 \mu \mathrm{m}$, accounting for $7.26 \%$ of the total volume $\left(\mathrm{d}_{50}=239.9 \mu \mathrm{m}\right)$. In the long SRTs reactors of 25 and $35 \mathrm{~d}$, floc diameters decreased, and mode floc sizes were $275.4 \mu \mathrm{m}$ $\left(\mathrm{d}_{50}=208.9 \mu \mathrm{m}\right)$ and $182.0 \mu \mathrm{m}\left(\mathrm{d}_{50}=182.0 \mu \mathrm{m}\right)$, respectively. The $35 \mathrm{~d}$ SRT floc size seemed to have decreased $71 \%$ compared to the $10 \mathrm{~d}$ SRT.

Floc diameter decreased as SRTs increased from 10 to $25 \mathrm{~d}$, corresponding d[4,3] were $634 \mu \mathrm{m}>283 \mu \mathrm{m}>222 \mu \mathrm{m}<305.8 \mu \mathrm{m}$, similar to the findings of Wilén and Balmér (1999). There are many factors that may have influenced the average particle size of flocs; for example, increased organic loadings produce larger flocs (Barbusinski and Koscielniak, 1995). As shown in Section 3.2, the influent remained the same in all reactors, but MLSS increased with increasing SRTs. Organic loading therefore decreased from 2.0 (g $\mathrm{COD} / \mathrm{g}$ biomass d) to 0.6 (g COD $/ \mathrm{g}$ biomass $\mathrm{d}$ ), with an increase in SRT from 10 to $35 \mathrm{~d}$. Short SRTs can produce dispersed growth of bacteria and pinpoint flocs (Bisogni and Lawrence, 1971; Pipes, 1979; Knocke and Zentkovich, 1986; Eriksson et al., 1992). These factors therefore counteract each other, resulting in an inexact relationship between SRT and the average particle size.

Microenvironmental characteristics of DO diffusion in ASF vary with different particle sizes. Han et al. (2012) investigated microenvironmental characteristics of different particle sizes and found that DO concentrations in floc cores gradually decreased with an increase in floc particle size. It is suggested that larger flocs experience higher DO consumption in the periphery than small ones, leading to a sharp decrease in DO concentrations in the floc core. If DO is low, the center of the flocs could be in anaerobic or extreme anoxic condition, which would have an effect on the nitrification performance.

\subsubsection{Floc structure of ASF under low DO condition}

According to literature, filamentous bacteria present in the ASF could prompt the formation of large flocs (Sezgin et al., 1978). It was necessary to investigate the influence of filamentous bacteria growth on floc structure. One of the flocs morphological parameter is fractal dimension, which is known to vary with different organic matters, electrolyte concentrations, reactor hydraulic conditions, and microbial sludge communities (Berka and Rice, 2005). Fractal dimension has also been used in modeling floc morphological characteristics, settling velocity, and aggregation and breakup kinematics (Maggi et al., 2007). A large 2D-fractal dimension indicates that ASF are more regular and compact.

In this study, the 2D-fractal dimensions of flocs under different SRTs at low DO were measured by the imaging method to explore the relationship of floc structure and SRTs. Because the shape of the flocs was irregular, the value of $\ln (\mathrm{A})$ as a nondimensional parameter represented the area and size of flocs, and value of $\ln (\mathrm{P})$ represented the perimeter and surface property of flocs. As illustrated in Fig. $5, \ln (\mathrm{A}) / \ln (\mathrm{P})$ showed a uniform mathematical description of the sludges' structural features obtained from different reactors, the slope value accounts for the fractal dimension and the regular extent.

Microscopic images revealed that ASF were irregular and porous under low DO conditions, especially in the $10 \mathrm{~d}$ SRT reactor. And the ASF tended to be smaller and shaped more regularly in the long SRT reactors. Furthermore, the presence of filamentous bacteria was 

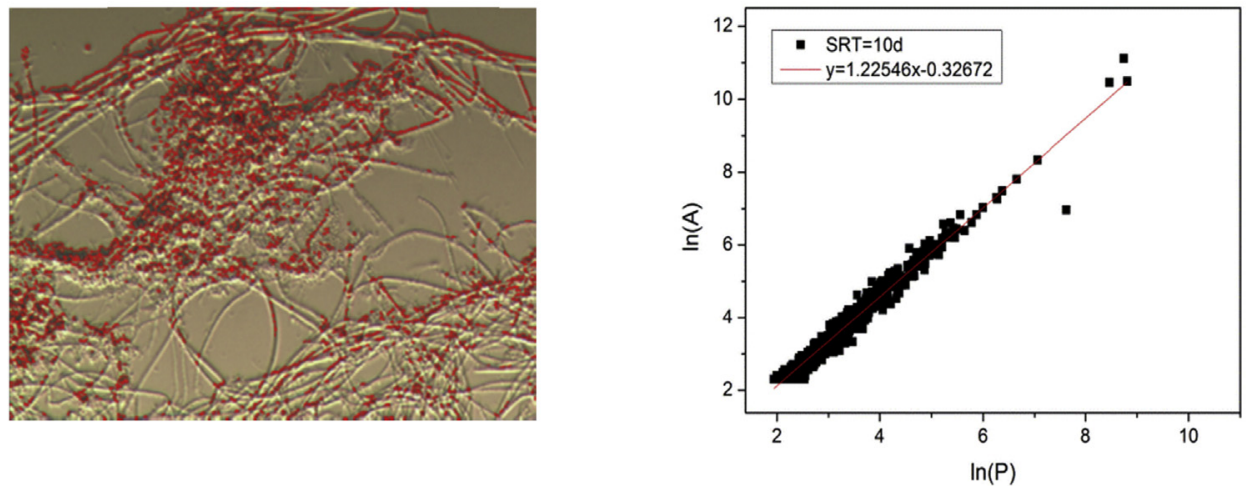

[1]
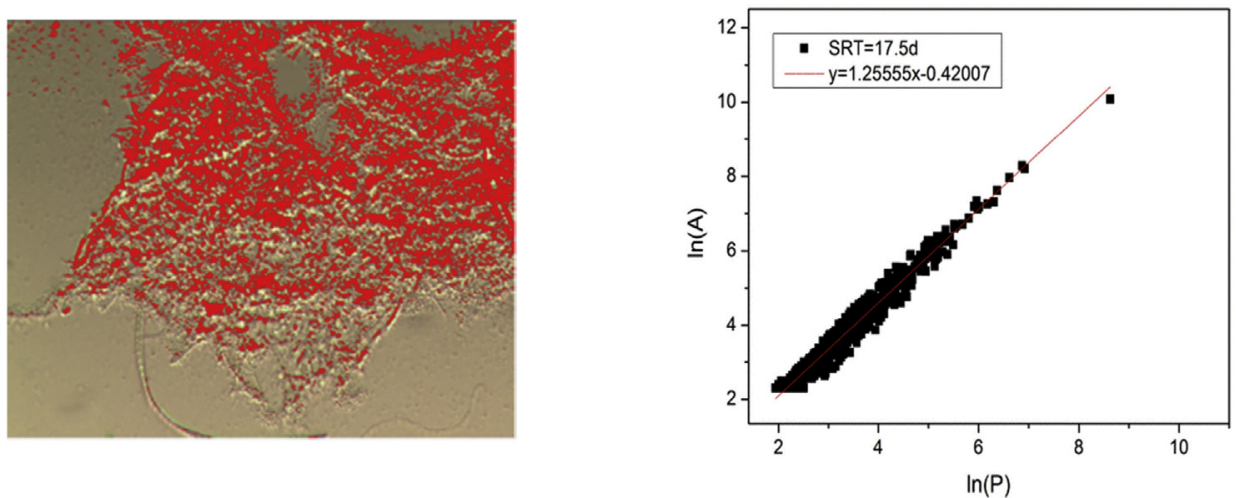

[2]
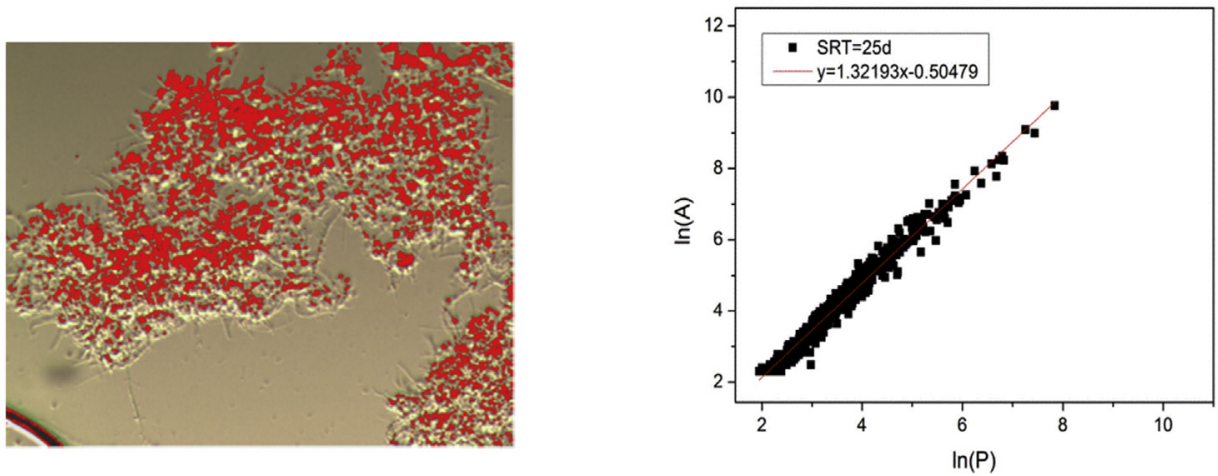

[3]
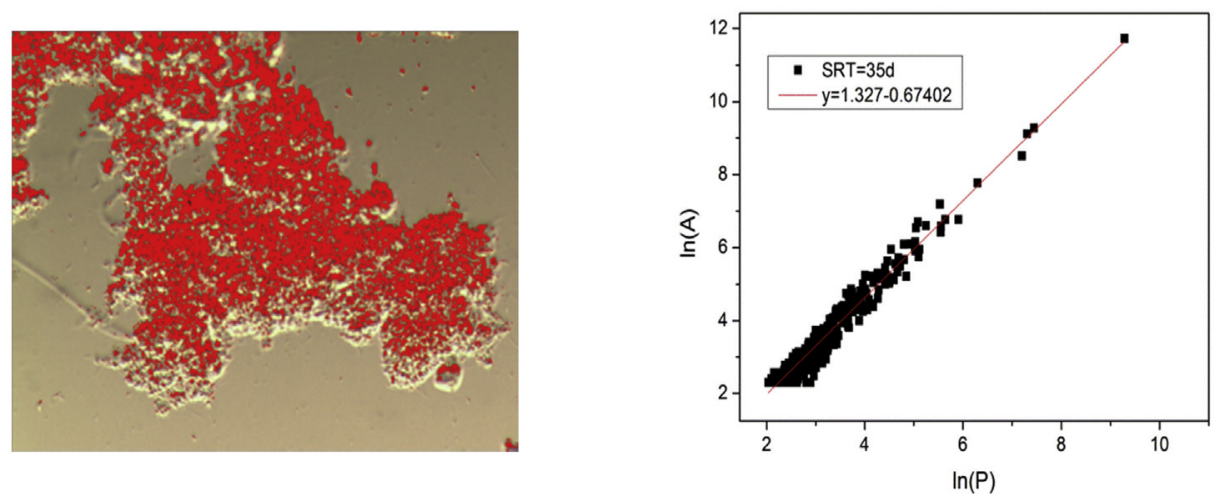

[4]

Fig. 5. Microscopic images of ASF and corresponding fractal dimensions ([1]SRT $=10 \mathrm{~d}$, [2] SRT $=17.5 \mathrm{~d}$, [3] SRT $=25 \mathrm{~d}$, [4] SRT $=35 \mathrm{~d}$ ). 


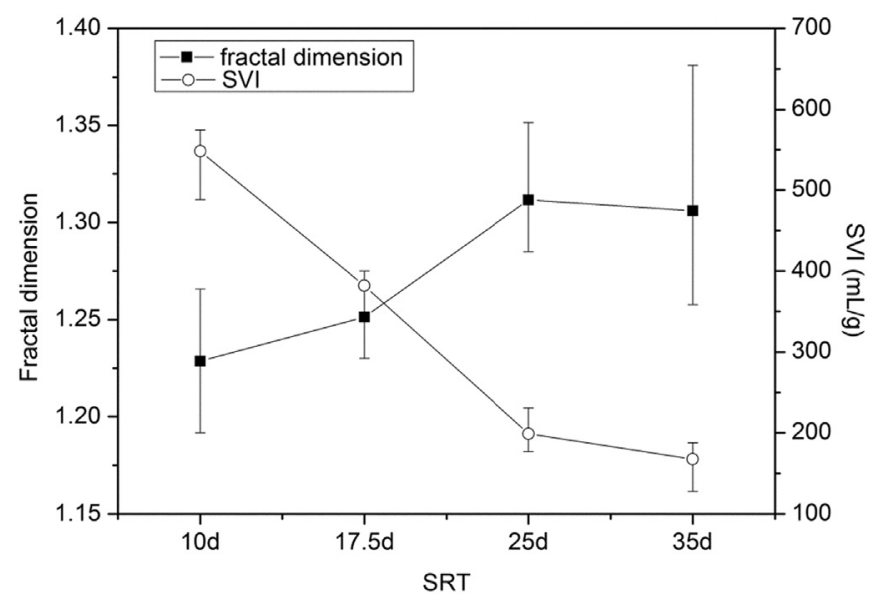

Fig. 6. Fractal dimensions and SVI of ASF with different SRTs in low DO conditions.

detected in all reactors, with higher numbers in microscopic images from short SRT reactors. With an increase in SRTs, visually filamentous bacteria seemed to decrease.

\subsubsection{Relationship between the floc structure and the settling performance}

Flocs settling is an important operating parameter because good settling performance of flocs results in better removal of solids from settling tanks. Fig. 6 shows that floc structure estimates based upon volume and fractal dimension are closely related to the settling performance.

Fractal dimensions were analyzed and calculated five times using average results. The average fractal dimension value of 10 , $17.5,25$, and $35 \mathrm{~d}$ SRTs reactors were $1.23,1.25,1.31$, and 1.30, respectively. It can be noted that an increase in SRTs to $35 \mathrm{~d}$ did not produce a large difference in the fractal dimension compared to a 25 d SRT.

Fig. 6 also showed the variation trend of fractal dimension and SVI under different SRTs. There was an inverse relationship between the SVI and fractal dimension, which means the floc structure influences the settling performance greatly. With an increase in SRTs, the average fractal dimension values decreased and the flocs visually became more regular and compact. In addition, the diameters of flocs with longer SRT were larger than those with shorter SRTs. Thus, the compact and small flocs have good sedimentation ability.

There were close relationships among EPS quantity per unit sludge, settling performance, fractal dimension values, and SRTs. EPS was the fundamental structure of the floc matrix, facilitating the aggregation of cells and formation of large flocs (Wingender et al., 1999). The change in EPS concentration would influence the 2D-fractal dimensions of the flocs and the sedimentation ability. On the basis of extensive statistical data analysis by Liao et al. (2001), it was found that an excess of EPS may not be conducive to sludge flocculation due to the steric-hindrance effect impeding further contact between the cells. In this study, because of the lower EPS quantity per unit of sludge under long SRTs conditions, floc aggregation to form zoogloea was found to occur more easily.

It has been shown that low DO conditions cause poor settling performance of ASF, mainly due to excessive growth of filamentous bacteria and the formation of porous flocs (Wilén and Balmér, 1999). However, in our study, we found that if activated sludge systems run steadily over a long term, a long SRT reactor can be more resistant to the adverse effects of low DO. Visually filamentous bacteria appeared more in the $10 \mathrm{~d}$ SRT reactor, and SVI increased to $548.2 \mathrm{~mL} / \mathrm{g}$. When SRT was increased to $35 \mathrm{~d}$, the flocs became more regular and compact, leading to a smaller floc size and lower SVI $(167.7 \mathrm{~mL} / \mathrm{g})$. Long SRTs can therefore diminish the adverse effects of low DO concentrations on the settling performance. Moreover, our results seemed to suggest that nutrient removal performance was also improved because of a higher oxygen diffusion property.

\section{Conclusions}

Smaller floc size and less EPS lead to high oxygen diffusion rate. Our results suggested that it may be beneficial to the nitrification process when oxygen easily penetrates the floc. ASFs with long SRTs seemed to be more resistant to the adverse effects of low DO concentration, resulting in better nitrification.

Less EPS also seemed to cause a decrease in the SVI. Visually filamentous bacteria started decreasing, and flocs became more regular and compact, which seemed to improve settling performance. Mode floc diameter increased with shorter SRT. No correlation between average floc diameter and SRT was found in this study.

\section{Acknowledgments}

This research was financially supported by the National Science and Technology Major Project (No. 2013ZX07314-001).

\section{References}

APHA, AWWA, WEF, 1999. Standard Methods for the Examination of Water and Wastewater, twentieth ed. American Public Health Association, Washington DC.

Barbusinski, K., Koscielniak, H., 1995. Influence of substrate loading intensity on floc size in activated sludge process. Water Res. 29 (7), 1703-1710.

Berka, M., Rice, J.A., 2005. Relation between aggregation kinetics and the structure of kaolinite aggregates. Langmuir 21 (4), 1223-1229.

Bisogni Jr., J.J., Lawrence, A.W., 1971. Relationship between biological solids retention time and settling characteristics of activated sludge. Water Res. 5, 753-763.

Chakraborti, Rajat K., Atkinson, Joseph F., Van Benschoten, John E., 2000. Charac terization of alum floc by image analysis. Environ. Sci. Technol. 34 (18), 3969-3976.

Chang, C.Y., Tanong, K., Xu, J., Shon, H., 2011. Microbial community analysis of an aerobic nitrifying-denitrifying MBR treating ABS resin wastewater. Bioresour. Technol. 102, 5337-5344.

Dubois, M., Gilles, K.A., Hamilton, J.K., Rebers, P.A., Smith, F., 1956. Colorimetric method for determination of sugars and related substances. Anal. Chem. 28, $350-356$.

Dulekgurgen, E., Dogruel, S., Karaham, Ö., Orhon, D., 2006. Size distribution of wastewater COD fractions as an index for biodegradability. Water Res. 40 (2), $273-282$.

Eriksson, L., Steen, I., Tendaj, M., 1992. Evaluation of sludge properties at an activated sludge plant. Wat. Sci. Technol. 25 (6), 251-265.

Fan, H.T., Qi, L., Liu, G.-H., Zhang, Y.K., Chen, X.L., Wang, H.C., 2014. Promotion and inhibition of oxygen transfer under fine bubble aeration by activated sludge. Water Environ. J. 28 (3), 434-441.

Guo, J.H., Peng, Y.Z., Wang, S.Y., Zheng, Y.N., Huang, H.J., Zhongwei Wang, Z.W., 2009. Long-term effect of dissolved oxygen on partial nitrification performance and microbial community structure. Bioresour. Technol. 100, 2796-2802.

Han, Y.P., Liu, J.X., Guo, X.S., Li, L., 2012. Micro-environment characteristics and microbial communities in activated sludge flocs of different particle size. Bioresour. Technol. 124, 252-258.

Karaham, Ö., Dogruel, S., Dulekgurgen, E., Orhon, D., 2008. COD fractionation of tannery wastewaters-particle size distribution, biodegradability and modeling. Water Res. 42 (4-5), 1083-1092.

Knocke, W.R., Zentkovich, T.L., 1986. Effects of mean cell residence time and particle size distribution on activated sludge vacuum dewatering characteristics. J. Wat Poll. Contr. Fed. 58 (12), 1118-1123.

Li, B., Bishop, P.L., 2004. Micro-profiles of activated sludge floc determined using microelectrodes. Water Res. 38 (6), 1248-1258.

Liao, B.Q., Allen, D.G., Droppo, I.G., Leppard, G.G., Liss, S.N., 2001. Surface properties of sludge and their role in bioflocculation and settleability. Water Res. 35, 339-350.

Liu, G.Q., Wang, J.M., 2013. Long-term low DO enriches and shifts nitrifier community in activated sludge. Environ. Sci. Technol. 47, 5109-5117.

Lowry, O.H., Rosebrough, N.J., Farr, A.L., Randall, R.J., 1951. Protein measurement with the folin phenol reagent. J. Biol. Chem. 193, 265-275.

Maggi, F., Mietta, F., Winterwerp, J.C., 2007. Effect of variable fractal dimension on 
the floc size distribution of suspended cohesive sediment. J. Hydrol. 343 (1-2), 43-55.

McCarty, P.L., Bae, J., Kim, J., 2011. Domestic wastewater treatment as a net energy producer-Can this be achieved? Environ. Sci. Technol. 45 (17), 7100-7106.

Mueller, J.A., Boyle, W.C., Popel, H.J., 2002. Aeration: Principle S and Practice. CRC Press, Boca Raton, USA.

Namkung, E., Rittmann, B.E., 1986. Soluble microbial products (SMP) formation kinetics by biofilms. Water Res. 20, 795-806.

Park, H.D., Noguera, D.R., 2004. Evaluating the effect of dissolved oxygen on ammonia-oxidizing bacterial communities in activated sludge. Water Res. 38 (14-15), 3275-3286.

Pipes, W.O., 1979. Bulking, deflocculation, and pinpoint floc. J. Wat. Poll. Contr. Fed. 51 (1), 62-70.

Satoh, H., Ono, H., Rulin, B., Kamo, J., Okabe, S., Fukushi, K., 2004. Macroscale and microscale analyses of nitrification and denitrification in biofilms attached on membrane aerated biofilm reactors. Water Res. 38 (6), 1633-1641.

Sezgin, M., Jenkins, D., Parker, D.S., 1978. A unified theory of filamentous sludge bulking. J. Water Poll. Contr. Fed. 50 (2), 362-381.

Strous, M., Pelletier, E., Mangenot, S., Rattei, T., Lehner, A., Taylor, M.W., Horn, M., Daims, H., Bartol-Mavel, D., Wincker, P., 2006. Deciphering the evolution and metabolism of an ANAMMOX bacterium from a community genome. Nature 440 (7085), 790-794.

Wang, L., Lv, Y.T., Wang, X.D., Yang, Y.Z., Bai, X.R., 2011. Micro-analysis of nitrogen transport and conversion inside activated sludge flocs using microelectrodes. Front. Environ. Sci. Eng. China 5, 633-638.

WEF and ASCE, 2001. Aeration-a Wastewater Treatment Process. Water
Environment Federation, New York, USA

Wilén, B.-M., Balmér, P. 1999. The effect of dissolve d oxygen concentration on the structure, size and size distribution of activated sludge flocs. Water Res. 33 (2), $391-400$.

Wilén, B.-M., Lumley, D., Mattsson, A., Mino, T., 2008. Relationship between floc composition and flocculation and settling properties studied at a full scale activated sludge plant. Water Res. 42 (16), 4404-4418.

Wingender, J., Flemming, H.C., Neu, T.R., 1999. Introduction-what are bacterial extracellular polymeric substances? In: Wingender, J., Neu, T.R., Flemming, H.C. (Eds.), Microbial Extracellular Polymeric Substances. Springer, Berlin, pp. 1-19.

Wu, J., Jiang, X., Wheatley, A., 2009. Characterizing activated sludge process effluent by particle size distribution, respirometry and modelling. Desalination 249 (3), 969-975.

Yu, H., Wang, Z., Wang, Q., Wu, Z., Ma, J., 2013. Disintegration and acidification of MBR sludge under alkaline conditions. Chem. Eng. J. 231, 206-213.

Zeng, W., Li, B., Wang, X.D., Bai, X.L., Peng, Y.Z., 2014. Integration of denitrifying phosphorus removal via nitrite pathway, simultaneous nitritation-denitritation and anammox treating carbon-limited municipal sewage. Bioresour. Technol. 172, 356-364.

Zhou, X.-H., Shi, H.-C., Cai, Q., He, M., Wu, Y.-X., 2008. Function of self-forming dynamic membrane and biokinetic parameters' determination by microelectrode. Water Res. 42 (10/11), 2369-2376.

Zita, A., Hermansson, M., 1994. Effects of ionic strength on bacterial adhesion and stability of flocs in a wastewater activated sludge system. Appl. Environ. Microb. 60, 3041-3048. 